\title{
Europeanization and Social Movement Mobilization during the European Sovereign Debt Crisis: The Cases of Spain and Greece
}

\author{
Europeización y movilización de los movimientos sociales \\ durante la crisis de la deuda soberana europea: los casos \\ de España y Grecia
}

\begin{abstract}
The article addresses Europeanization of social movements in the context of the European Sovereign Debt Crisis. Europeanization occurs when movements collaborate, or make horizontal communicative linkages with movements in other countries, contest authorities beyond the state, frame issues as European and claim a European identity. The article presents a theoretical framework and research design for measuring the degree of social movement Europeanization followed by results of a pilot study on mobilization in Spain and Greece during 2011. While many contentious action events studied only encompassed the domestic arena, the pilot study showed a relatively high degree of Europeanization in the Greek case, suggesting the viability of future research.
\end{abstract}

Keywords: Europeanization, European Union, Financial Crisis, Social Movements

Resumen

El presente artículo aborda la europeización de los movimientos sociales en el contexto de la crisis de la deuda soberana europea. La europeización se produce cuando los movimientos colaboran, o establecen vínculos horizontales, con movimientos de otros países, contestan a las autoridades más allá de los límites del Estado-nación, identifican cuestiones como europeos y reclaman una identidad europea. El artículo presenta un marco teórico y un diseño investigación para medir el grado de europeización de los movimientos sociales seguido por los resultados de un estudio piloto de la movilización en España y Grecia durante el año 2011. Mientras que muchas de las acciones de protesta estudiadas solamente apelaban al ámbito doméstico, el estudio piloto muestra un relativamente alto grado de europeización en el caso griego, lo que sugiere la viabilidad de futuras investigaciones.

Palabras clave: europeización, Unión Europea, crisis financiera, movimientos sociales 


\section{INTRODUCTION}

In this article we examine the Europeanization of social movements in the context of the European Sovereign Debt (ESD) Crisis. We argue that Europeanization of social movements occurs when movements collaborate, or make horizontal communicative linkages with movements in other countries, contest authorities beyond the state, frame issues as European and claim an European identity. An interest in the possible Europeanization of social movements emerged in the mid-1990s as scholars observed EU-oriented grass roots mobilization by established movements such as the environmental movement and more spontaneous grass roots mobilizations on issues ranging from EU fishing rules, agricultural subsidies, unemployment in the EU and plant closures in transnational companies (Tarrow, 1995; Imig and Tarrow, 2000; Rucht, 2002; Marks and McAdam, 1996). It also grew out of work by social movement scholars on the transnationalization of protest in the context of globalization (Tarrow, 1995; Della Porta and Tarrow, 2005; Reising, 1999; Smith, 2002 and 2007). Moreover, since the start of the international financial crisis in 2008, a large, interdisciplinary literature has addressed the global wave of contention incorporating the Arab Spring, Occupy movements but also many European anti-austerity movements (among others) (eg. Castells, 2012; Flesher and Cox, 2013; Tejerina, 2013; Worth, 2013; della Porta and Mattoni, 2014; Flesher, 2014).

A common theme of these literatures is that the degree of social movement Europeanization tends to be rather low. In their protest event analysis surveying social movement actions in 12 Eu member states between 1984 and 1998, for instance, Imig and Tarrow showed "most people, for most issues, continue to protest against national or subnational targets about domestic issues» (2000: 84). Only about 5\% of protest events during that time were categorized as European protests (Imig and Tarrow 2000). Koopmans, Erbe and Meyer draw similar conclusions, albeit employing different methods - cross-national, semi-structured interviews with social movement organizations (and other domestic and supranational actors) from seven countries (2010). They argue that the strategic repertoire of national political actors, including both 'inside' strategies addressing public administrations, parliamentarians and the courts, and 'public-related strategies' focusing on the media, public information campaigns and protest, are still primarily focused on the national level (Koopmans, Erbe and Meyer, 2010: 234). Della Porta and Caiani's study, compiled from the same data set as that used by Koopmans, Erbe, and Meyer (2010), also supports the conclusion of 'low 
Europeanization' of the domestic public sphere (Della Porta and Caiani, 2009). Similarly, various scholars examining the global wave of protest following the international financial crisis, have argued that unlike the earlier, paradigmatic case of transnational collective action, the global justice movement, the current global wave of contention mostly intends, as Flesher put it, «to reclaim the nation state as a locus and focus of action» (2014: 183, see also Kaldor and Selchow, 2013; della Porta and Mattoni, 2014). We contend, however, that there are good reasons for re-examining the case that social movement Europeanization is insignificant.

In the first place, data pointing to low social movement Europeanization is now fairly old. Imig and Tarrow's research examined data from 1984 to 1988 while Koopmans et al and Della Porta and Caiani use data from 1990, 1995 and 2002-3 (Koopmans and Statham, 2010). Furthermore, even though a large portion of the literature on the recent global wave of mobilization examines European anti-austerity movements, it tends to neglect processes of Europeanization. Rather, studies that look beyond the domestic arena tend to focus on transnational dimensions of collective action, with a predominant interest in transnational diffusion, addressing the spread of mobilization frames (e.g. calls for 'real democracy'), tactical repertoires (e.g. occupation of public spaces), slogans (e.g.'We are the 99\%') and movement labels (e.g. Indignados and Occupy) (della Porta and Mattoni, 2014; Flesher, 2014; Kousis, 2014; Tejerina et al., 2013). And yet, a specific focus on the Europeanization of social movements is necessary to understand Europe as a movement space on its own terms (Flesher and Cox, 2013; Stratham and Trenz, 2013), while a focus on a broader range of Europeanization dimensions than diffusion will provide a better way of gauging the significance of 'Europe' in social movement mobilization.

Moreover, in the context of the ESD crisis, it is reasonable to expect, $a$ priori, a more significant degree of social movement Europeanization. In the first place, the accumulation of decision-making authority at the eu level is perhaps the most cited rationale for a reorientation of social movement activity to that level (see for example, Tarrow, 1995; Imig and Tarrow, 2000; Rucht, 2002: Della Porta and Caiani, 2009, Statham and Koopmans, 2010), and the Eu has, through the course of ESD crisis, become one of the key crisis actors. Initially, member states, in cooperation with the Commission and the ECB, set up two temporary funds: the European Financial Stabilization Mechanism (EFSM) and the European Financial Stability Facility (EFSF) (May 2010June 2013), with a total lending capacity of 500 billion euros. In autumn 2012, the EFSF was replaced by the permanent European Stabilization Mecha- 
nism (ESM), solidifying the EU mechanisms of economic crisis management. Member states also changed the 'no bail-out' clause in the Treaty of the European Union, paving the way for the first EU and IMF bail-out for Greece in 2010, which was followed by bailouts for Ireland (2010), Portugal (2011) and Cyprus (2012). Spanish banks were also given Eu loans in 2012. Loans were granted on the condition that governments implement severe austerity measures, supervised by Eu and IMF experts. These measures led to increased coordination between the European Commission, ECB and IMF - referred to as the 'Troika'. In addition, Eu member states agreed a number of measures for closer surveillance and coordination of budgetary and economic policy among Eurozone states. These include the so-called 'six pack' of legislative measures, entering into force in December 2011, which covered fiscal and macroeconomic surveillance and strengthening the Stability and Growth Pact, and the 'European semester', whereby member states coordinate their economic policies while national budgets are still in preparation. In 2012, twenty-five Eu member states (but not UK and the Czech Republic) signed the Treaty on Stability, Coordination and Governance, which introduced new more stringent surveillance and coordination rules for economic policies.

Furthermore, some of the obstacles to social movement Europeanization may have been mitigated, if not overcome. Imig and Tarrow, for instance, have argued that «movements are most likely to take root among pre-existing social networks in which relations of trust, reciprocity and cultural learning are stored" $(2000,79)$. As such, while it is 'plausible to think of transnational identities developing around parallel claims in widely differing sites of conflict', this is more difficult than more local process of identity formation «embedded in everyday life» and involving family, friends neighbors and work (Imig and Tarrow, 2000: 80). Furthermore, they point to the obstacle of high «transaction costs of linking [groups in different countries experiencing similar problems] into integrated networks across national boundaries» (Imig and Tarrow, 2000, 80). However, it may be that technological innovation facilitating communication between actors across national boundaries (Castells, 2012), as well as the experience gained from the development of new networks among social movements prior to the crisis could help overcome some of these obstacles. As we spell out in more detail below, Della Porta and Caiani's work on European social forums provides evidence to suggest that some sense of collective identity, social networks of trust, reciprocity and learning may have already taken root among participants in certain pre-crisis European protests, which addressed issues not dissimilar to those at the center of many anti-austerity protests (2009). 
In order to examine the significance of social movement Europeanization, the article begins by presenting a theoretical framework, built on, but extending, the work of previous studies, to measure the degree of social movement Europeanization. We then turn to present the outline of a research design which can be employed to examine empirically the degree of social movement Europeanization. In the final section we present the findings of a pilot study, which focused on social movement mobilization in Spain and Greece between May and June 2011 and reflect on avenues for future research. In this section we observe that the largest category of contentious action events in both Spain and Greece was action focusing entirely on the domestic arena during the period studied. However, in an indication of the viability of further research on the Europeanization of social movements in the context of the ESD crisis, we see in the Greek case evidence to suggest a relatively high degree of Europeanization, given that the percentage of events which exhibited at least one dimension of Europeanization was higher than the number of events strictly focused on the domestic arena.

\section{DEGREES OF EUROPEANIZATION: MOVEMENT STRATEGY, IDENTITY AND HORIZONTAL REFERENCING}

\subsection{Previous work on Europeanization of Social Movements}

A major preoccupation of the literature on the Europeanization of social movements hitherto has been with movement strategy. More specifically, researchers have been particularly interested in the extent to which the gradual accumulation of decision making and management authority at the Eu level has been accompanied by changes in social movement mobilization from that principally involving fellow nationals and focused on state actors, on the one hand, to also involve and target actors and audiences from other states and the Eu, on the other hand (see for example,Tarrow, 1995; Imig and Tarrow, 2000; Rucht, 2002; Della Porter and Caiani, 2010; Statham and Koopmans, 2010). These studies have helpfully distinguished between 'non-Europeanized' grass-roots collective action which does not address eu issues at all and various forms of Europeanized social movement action.

Imig and Tarrow distinguish between four types of European protests: 1 . Typical Domestic Protests «in which national actors target domestic opponents», effectively non-Europeanization. 2. Coordinated Domestic Protest, involves a transnational coalition of actors against a domestic political target 
(such as a national government). 3. Domestication of conflict occurs when «national actors protest at home against policies of the EU».4. Transnational contention, in which «transnational coalitions of actors target the Eu or other supranational or transnational actors in response to EU policies» (Imig and Tarrow, 2000: 78). This last category is subdivided into three further categories: a.International Cooperation, where «actors from various countries join together in linked and coordinated protest campaigns in each national setting against a shared antagonist»b. International Conflict, where "protesters have targeted, rather than joining with, their competitors from other nations»; and c. Collective European Protests, which are «major protest events [which] draw the participation of citizens from across the EU» (Imig and Tarrow, 2000: 86-7).

Della Porta and Caiani's conceptualization of social movement Europeanization builds on and extends Imig and Tarrow's early approach (Della Porta and Caiani, 2009). Firstly, Della Porta and Caiani identify a 'nation-state' model of Europeanization, where European actors emerge to challenge decision-makers in a European polity in parallel to mobilization by strictly national actors mobilizing only at the national level. More variegated strategies where social movements simultaneously address various territorial levels can take different forms. They may take a domestication path, which along the lines of Imig and Tarrow's (2000) conception cited above, social movements only mobilize at the national level in order to pressurize national governments to negotiate on their behalf in Eu bodies (Della Porta and Caiani, 2009: 14). A second type of variegated strategy involves externalization, where national actors «target the EU in an attempt to put pressure on their own governments» (Della Porta and Caiani, 2009: 15), a strategy which may be particularly attractive to actors who feel marginalized in domestic politics. And finally, European social movements may emerge, involving 'loose networks of national (and even local) and transnational groups' which simultaneously target and address claims to various polities, including domestic and European-level decision-makers (Della Porta and Caiani, 2009).

Patterns of mobilization identified by Imig and Tarrow, Della Porta and Caiani need not be limited to contention arising in Eu politics. For instance, Della Porta and Tarrow employ the concepts of domestication, externalization and transnational collective action (defined as coordinated international campaigns by networks of activists mobilizing against international actors, other states or international institutions) in work on transnational movements active on issues of global reach (2005). 
Implicit in studies such as these is the idea that the degree of social movement Europeanization varies in intensity, with domestication strategies addressing domestic authorities on eu issues arguably displaying a lower degree of Europeanization than the emergence of European social movements. Nevertheless, overlap in the way in which these typologies distinguish between different forms of mobilization provides the basis for conceptualizing varying degrees of social movement Europeanization with greater precision. The typologies principally focus on variation in 1) targets of social movement mobilization, or whether targets are principally domestic authorities, European authorities (including eu institutions and state authorities abroad), or both; 2) the nature of movement participants, or whether movement actors take action predominantly alongside fellow domestic actors, fellow European actors or both. A third dimension concerns issue framing and whether or not the issues provoking mobilization are conceived as predominantly domestic, or predominantly European or a combination of both.

Beyond a focus on movement strategy, the literature on Europeanization suggests two further elements that are relevant for assessing the degree of social movement Europeanization. The first concerns issues of identity. As mentioned above, Imig and Tarrow argue that one of the main the obstacles to transnational protests was the absence of common identities, a sense of solidarity and "pre-existing social networks in which relations of trust, reciprocity and cultural learning are stored»(2000: 79-80). This was because «social networks provide the interpersonal trust, the collective identities and the social communication of opportunities that galvanize individuals into collective action and coordinate their actions against significant others in a social movement» (Imig and Tarrow, 2000: 80). However, Della Porta and Caiani provide evidence to suggest that some sense of collective identity, social networks of trust, reciprocity and learning may have already taken root among participants in certain joint European protests centred on issues not dissimilar to those at the centre of anti-austerity protests (2009). In their study of European Social Forums and Eu counter summits, Della Porta and Caiani address the role of social movements in the construction of collective European identities through discourse and processes of communication (2009). The authors argue that the European arena offers social movements «opportunities to meet, build organizational networks, coordinate activity, and construct supranational discourses» and that «growing interaction facilitates the development of common, more or less, European identity» (Della Porta and Caiani, 2009: 96). Social movements and non-governmental organizations tended to privilege ties with 
similar civil society organizations rather than those with institutional actors or interest groups and this tight network of links also «favours the emergence of shared goals and collective identities on European issues» (Della Porta and Caiani, 2009: 80). Social movement organizations and nongovernmental organizations are not only more critical towards the Eu than other groups in their country, they are also more likely to frame Europe in their claims in identity terms by emphasizing «non-material aspects of the integration process, referring to an identity discourse (such as references to Europe as a community of values) and constitutional principles (especially democracy)» (Della Porta and Caiani, 2009: 80).

In contrast to much of the literature on European identity, which tends to equate identification with positive assessments of European integration (Bourne, 2015), the authors argue that social movements and non-governmental organizations develop the foundations of a common identity through critiques of contemporary institutions and the desire to construct an alternative Europe. Interview data showed that the emerging critique was not about «too much Europe', but 'not enough social Europe» (Della Porta and Caiani, 2009: 119). They also expressed criticisms of the perceived democratic deficit of the Eu, focusing on the limited powers of the European Parliament, lack of transparency, distance from civil society and accessibility for citizens. Furthermore, most civil society groups interviewed expressed support for a «different Europe» built from below by a «European movement» (Della Porta and Caiani, 2009: 123).

A final element draws on the concept of 'borizontal Europeanization' (Koopmans and Statham, 2010). This concept is drawn from work on the Europeanization of communication, which the authors argue is a central component of «Europe's ongoing search for a public» (Koopmans and Statham, 2010: 3). Horizontal Europeanization «consists of communicative linkages between different European countries» (Koopmans and Erbe, 2003: 6). There is a strong and a weak variant: «In the weak variant, the media in one country cover debates and contestation in another country, but there is no communicative link in the structure of claim-making between actors in different countries» (Koopmans and Statham, 2010: 38). It involves, for instance, the reporting of events in other countries. In the stronger variant, there is such a communicative link, and actors from one country explicitly address or refer to actors or policies in another European country'. Here the communicative link may take the form of external actors commenting on domestic policy developments or comparison across countries. Given our 
focus on social movements, rather than the media, the strong variant of horizontal Europeanization is of particular interest in this research.

\subsection{A new framework for measuring the degree of Europeanization}

These five dimensions of social movement mobilization - targets, participants, issue framing, identification and horizontal referencing can be combined to produce a new scale identifying six degrees of Europeanization.

Non-Europeanization involves national actors targeting domestic opponents and the issues provoking mobilization are conceived predominantly as domestic issues. There is no horizontal referencing to other movements or policies in other countries and no identity claims encompassing groups beyond the boundaries of the state. At the other end of the scale, very high Europeanization occurs when cross-nationally organized social movements in Europe target European actors and frame issues as European issues. Elements of the movement make cross-national references to policies or actors in other countries and make identity claims encompassing groups in other parts of Europe. Very high Europeanization does not require that social movement, participants, targets and issue framing are exclusively European in scope. Such movements may, for instance, simultaneously involve domestic and transnational actors, targeting domestic, eu and transnational authorities. Nevertheless, this conception of Europeanization is more demanding than that employed in previous work on social movement mobilization, insofar as it also requires evidence of horizontal referencing and identification. In between non-Europeanization and very high Europeanization are four additional categories: Very low Europeanization occurs when any one of the five dimensions of social movement mobilization - targets, participants, issue framing, identification and horizontal - occurs. Low Europeanization occurs when any two of the five dimensions of social movement mobilization occur. Moderate Europeanization occurs when any three of the five dimensions of social movement mobilization occur. High Europeanization occurs when any four of the five dimensions of social movement mobilization occur. 
Table 1

Degrees of Europeanization

\begin{tabular}{lc}
\hline Degree of Europeanization & $\begin{array}{l}\text { Number of Social Movement Europeanization di- } \\
\text { mensions (any of targets, participants, issue fram- } \\
\text { ing, identification and horizontal referencing) }\end{array}$ \\
\hline Very High & 5 \\
High & 4 \\
Moderate & 3 \\
Low & 2 \\
Very Low & 1 \\
Non-Europeanization & 0 \\
\hline
\end{tabular}

The advantage of this approach is that it provides a more explicit, and quantifiable, means of measuring social movement Europeanization, and one which takes into account a broader range of dimensions than previous studies. We acknowledge that this scale is rather abstract in its formulation and that there may appear to be a measure of arbitrariness in the selection of dimensions included in the scale. This is difficult to avoid entirely. We have tried to mitigate this problem by careful attention to a full range of what existing work on Europeanization suggests are relevant dimensions of social movement Europeanization. Moreover, we considered whether some dimensions of Europeanization ought to be given more weight in the calculation of the degree of Europeanization. Weighting one or other dimension more heavily is likely to have changed our findings. However, there does not appear to be a strong theoretical rationale to attribute, a priori, greater significance to one or other dimension. We hope further empirical analysis will provide greater insights in this regard.

\section{METHODS AND OPERATIONALIZATION OF KEY CONCEPTS}

A variety of methods can potentially be employed to examine social movement Europeanization in the context of the ESD crisis (Bourne and Chatzopoulou, 2015). However, a good starting point for examining the degree of social movement Europeanization is to employ Political Claims Analysis (PCA) 
(Koopmans and Statham, 1999; Koopmans and Rucht, 2002). This method uses newspapers as a primary source of data to collect both quantitative and qualitative data on a) targets, participants, issues and forms of contentious action (among other things) and b) the semantic content of claims made in the public sphere over time and across countries. The units of analysis are "public acts of claim making», or the strategic demands made by collective actors "within a specific contested issue field» (Koopmans and Statham, 1999: 206). Instances of claim making involve demands, criticisms or proposals related to the subject of inquiry. Data is collected on the behavior of both non-state actors, including civil society groups, such as labor unions and political parties, as well as state actors, such as the police, courts, legislatures and local, regional and supranational institutions. As Koopmans and Statham argue, this focus on a broad range of actors has the advantage of shifting «the focus on inquiry towards the coalitions, networks and conflict lines that connect and relate the different types of collective actors in a multiorganizational field» (1999: 206). PCA examines all forms of claim-making, whether routine or non-routine, conventional, or non-conventional, 'physical' (for example public demonstrations outside public buildings) or discursive (issuing press releases, consciousness-raising). This has the advantage of permitting analysis of the range of action repertoires employed, in contrast to protestevent analysis which is too "protest centric» and permits "appreciation of public discourse as a medium of social conflict and symbolic struggles» (Koopmans and Statham, 1999: 205).

PCA rests on the assumption that newspapers provide a "continuous record of public events and the visibility of the claims of actors» (Koopmans and Statham, 1993: 203). Newspapers are also seen as a medium through which social movements articulate political challenges in the public domain and by which actors «assign meaning to issues» in the public sphere (Koopmans and Statham, 1993: 203). They provide better and more detailed coverage than radio and television and reach a broad audience (Koopmans and Rucht, 2002), even if they do not provide the discursively richest source of analysis compared with other documents (Koopmans and Statham, 1999). It is also one of the few sources that can be used to build up systematic and long-term databases on contentious action (Caiani, Della Porta and Wagerman, 2013: 34: Koopmans and Rucht, 2002). Nevertheless, there are various problems arising from reliance on newspapers as a primary source of data, including systematic bias in coverage of the types of demonstrations covered (e.g. large and violent demonstrations more likely to be covered than smaller ones) and issues around which mobiliza- 
tion occurs (eg. protest on issues resonating with 'media issue attention cycles' are more likely to be covered than those that are not) (McCarthy et. al., 1996; Koopmans and Rucht, 2002).

Various strategies can be employed to limit the impact of such problems. One response to selection bias is to code events reported in multiple newspapers, identifying, matching and combining information on events reported in different newspapers (Koopmans and Rucht, 2002). Another response is to employ other sources of data in tandem with newspaper records. ${ }^{1}$ An additional response to the problem of selection bias is to delimit the nature of claims made on the basis of newspaper data. This is an approach used by Della Porta and Caiani who reduce the risks of selection biases introduced by the practices of journalism by delimiting their research interest specifically to "public claim making - thus in the claims that reach the pages of a newspaper» (2009: 29). Without denying that some actors are more dependent on the media than others, they argue that «the printed media are one of the most important areas of public claim-making, and that most actors, will, at one stage or another, try to make their views public» (2009: 30). In a similar vein, Koopmans and Statham argue that claims made in newspapers are the result of «actual strategic actions of the claim makers in the public sphere» (1999: 216), while Della Porta et al. argue:

With precaution and many interpretative caveats, press-based protest event analysis allows for controlling, if not the real amount and forms of protest, at least the associations among specific characteristics of protest repertoires as well as very general trends (Della Porta, Caiani and Wagerman (2012:34).

\subsection{Pilot study}

We use PCA in a pilot study of political claim making events in May and June 2011 in Greece and Spain. The purpose of the pilot study is to clarify procedures for operationalizing key concepts, discussed below, and to examine the feasibility of undertaking further investigation on the Europeanization of social movements. Specifically with regard to the latter, we selected two country case-studies and a time period in which mobilization

1 Police records have been one important alternative sources of data on protest events (McCarthy et. al., 1996; Koopmans and Rucht, 2002), although as Koopmans and Rucht argue, police records may themselves be subject to selectivity biases $(2002,251)$. Moreover, as comparisons between reporting of events from newspapers and police records show, correlations of events reported in newspapers and police records over the longer term are high, suggesting newspapers may be more reliable than is sometimes thought (Koopmans and Rucht, 2002, 238). 
around issues of the ESD crisis were very high. In Spain, mobilization against austerity crystallized around the Indignados (the outraged) movement, also known as 15M, signifying the date of the first mobilization on 15 May 2011. On this date tens of thousands of citizens joined demonstrations around the country in protest against the Spanish government and eu responses to the global financial crisis, especially cuts in education, welfare and social problems and expressing frustration at their exclusion from an elitist political system dominated by the two main center-left and center-right parties, international organizations and financial institutions (Castañeda, 2012; Hughes, 2011). After the 15 May protests, many stayed on and occupied public squares around the country for a few weeks, with the biggest demonstrations in the Puerta del Sol in central Madrid and Plaza Cataluña in Barcelona. Although large scale anti-austerity protests in Greece had taken place earlier, new austerity measures were announced in May and June 2011 which again provoked the mobilization of the civil society and triggered more street protests. These protests are often referred to as the Greek 'indignados' or 'outraged citizens', in a clear reference to the example of the Spanish movement. Incidents of violence against public buildings, and physical and verbal attacks against public figures (i.e. the President and the chair of the Parliament) took place on various occasions, especially in the area in front of the Parliament (Psimitis, 2011). Given the intensity of antiausterity mobilization in Greece and Spain during the time period examined - and the fact that the eu played a high profile role in the promotion of austerity programs -we can consider these cases as 'crucial cases' (Eckstein, 1979). That is, they are cases in which we could expect to find a significant degree of evidence of social movement Europeanization if it could be found at all. We consider social movement Europeanization to be significant if there are more events with at least one dimension of Europeanization (targets, participants, issues, identities, horizontal referencing) than those without any Europeanization at all. If we did not find this evidence, then there would be grounds for considering that further study into social movement Europeanization may not be very fruitful.

In the pilot study data was retrieved from two national newspapers for each country (Kathimerini and Avgi for Greece and El Mundo and the online newspaper, Publico.es for Spain). These newspapers were chosen because they tend to present political affiliations broadly from the center right or left in ideological terms. They also represent mainstream and nonmainstream media outlets. They are published and read by national audiences and have a good reputation for their consistent and extensive cover- 
age. From these newspapers we compiled and analyzed a sample of contentious actions. We searched for articles on contentious action in the international and national news sections of the four newspapers. For each newspaper we read and coded articles for two editions each week (on Tuesdays and Fridays). We selected articles for analysis if the title or first two paragraphs indicated they were likely to provide relevant data. We did not keep a record of events where the target, participants or issue at the heart of a protest were not clear. We used computer software (MAXQDA) for managing coded data. Using MAXQDA, we were able to using open-coding to keep a record of different types of targets, participants, issues, identity statements and horizontal references, as well as information on the forms, size, place and other features of protest.

In total we observed and coded 163 events for Spain and 148 for Greece - in total 311 events. We focused on protest by non-state actors, but we also code protests by representatives of public authorities from multiple territorial levels (domestic, eu and transnational) when they collaborate with those non-state actors. We included a broad range of contentious action forms, which ranged from public demonstrations, occupation of public spaces, theatrical events, legal action, public statements and speeches as well as acts of civil disobedience and violence against property or persons. In future research, we will address issues of social movement mobilization using other sources of data, including twitter feeds and internet publications.

\section{'Bottom-up' Europeanization approach}

One final methodological point needs to be made. In Europeanization research, the distinction between top-down and bottom-up approaches has long been considered significant from a methodological point of view (Lyngaard, 2011; Radaelli, 2004). Top-down studies address the impact of EU integration on the domestic level and usually concentrate on how specific regulatory frameworks trigger change at the domestic level. On the other hand, bottom-up Europeanization research designs start from the domestic level and examine actors, ideas, rules and styles and how they change through time (Lyngaard 2011). This study is a bottom-up Europeanization study insofar as we focus analytical attention on movements in Spain and Greece and their relationships with other domestic, European and transnational actors and arenas. This tends to be a distinctive characteristic of re- 
search on the Europeanization of social movements in general (eg. Della Porta and Caiani, 2009: 25).

More fundamentally, one of the advantages of selecting a bottom-up research design over top-down ones is that it permits us to address one of the principal critiques of Europeanization research, namely the tendency to overestimate the importance of the eu as an explanatory factor for observed changes in domestic behavior (Radaelli and Pasquier 2007: 40). In other words, the problem is that if researchers only focus on European developments they may spuriously attribute changes to European-level events and processes. Put differently, changes such as the emergence of social movements may in fact be due to a variety of factors - such as domestic corruption scandals, changes in political culture, such as declining trust in political institutions and political parties, or international factors related to globalization and transnationalization of politics. Our bottom-up research design permits us to be sensitive to domestic explanations for social movement mobilization and to deal with transnational dimensions of social movement mobilization. Specifically with regard to the latter, therefore, we code contentious action where targets, participants, issues, identities and horizontal references are transnational, in addition to where these dimensions of social movement mobilization can be observed as European.

\subsection{Operationalizing theoretical concepts}

Operationalizing varying 'degrees of Europeanization' was a complex process. As mentioned, one of the main objectives of the pilot study was to develop clear procedures for coding data relating to these five key variables, namely targets of contentious action, participants in that action, how issues mobilizing protest were framed, identities and horizontal referencing. For the first four variables, we started by differenting predefined 'closed' categories of 'domestic', 'European' and 'transnational'. Differentiation among the types of targets (e.g. governmental executive, business, Eu institutions etc), types of participants (e.g. NGOS, platforms, trade unions, unorganized citizens), types of issues (e.g. ESD crisis-related, and non ESD crisis-related) and types of identities (e.g. national identities, movement identities, European identities, cosmopolitian identities) was not predetermined. We used open-coding - and frequent communication between the coders - to add new codes as they emerged from data. By definition, the concept of horizontal referencing could only be coded as either European or transnational (see below). 
We coded as 'targets' of contentious action organizations, institutions or arenas with decision-making capacity or political influence which appeared from information provided in the newspaper articles to be either implicitly or explicitly the subject of contentious action. They correspond to what Koopmans and Erbe (2003: 9) define as an 'addressee', or the actor held responsible for implementing the claim (if agreement could be obtained), or who is the target of criticism or support.Targets are differentiated according to whether they correspond to domestic, European and transnational or any of the combinations (e.g. domestic and Eu simultaneously). Targets were almost always named and this made categorization relatively straight-forward. Examples of targets included both governmental and non-governmental actors such as the state executive, police, judiciary, local and regional governments, trade union, churches, local and transnational-companies, banks, EU institutions like the Commission or the Council, or international bodies like the IMF or the TROIKA. For example, in the case of a protest by local government employees in Greece - who were facing unemployment or were not being paid their salaries because of budget cuts (due to the crisis) - the local government was coded as target because protestors specifically directed their attention to this body. ${ }^{2}$ Sometimes there were multiple targets. If protest focused on a decision taken by the government as a response to a demand by Eu institutions - such as an increase of working hours in the public sector or decrease in public spending for salaries in order to receive the Eu bailout - the targets are coded as both national government and Eu institutions. ${ }^{3}$

As mentioned above, in our study we focus on protest by non-state actors, but we also code protests by representatives of public authorities from multiple territorial levels when they collaborate with those non-state actors. Participants correspond to what Koopmans and Erbe call the 'claim maker' or 'claimant', or the actor who makes a demand, proposal, appeal or criticism (2003: 9). The most common form of participants were - not surpisingly non-governmental organizations, interest groups and platforms. There were also examples of spontaneous events were participants were often individual citizens. Different types of participants could take part in the same event. For example, the big demonstration on 5 May 2011 in Greece included mem-

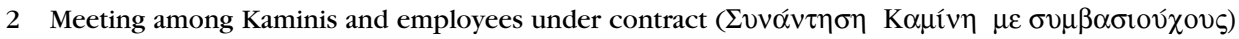

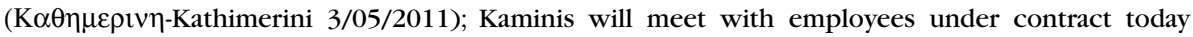

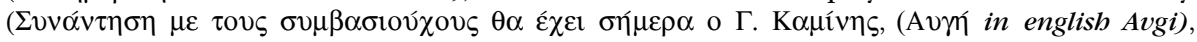
3 May 2011.

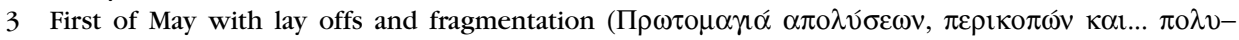

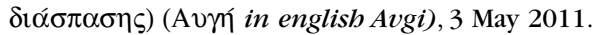




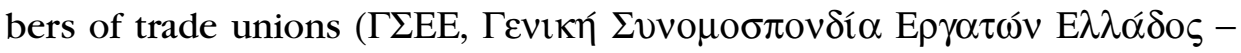

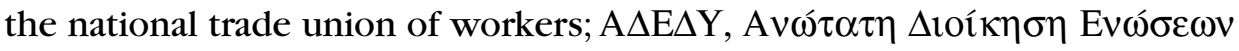
$\Delta \eta \mu о \sigma i \omega v$ Y $\pi \alpha \lambda \lambda \omega \lambda \omega v$ - the national trade union of civil servants); participants from political parties, from the left (eg. $\Sigma$ YPIZA); as well as pensioners, unemployed and unorganized citizens. ${ }^{4}$ Participants were categoried according to whether they corresponded to domestic, eu and transnational or any of the combinations (e.g. domestic and eu simultaneously). Most participants mentioned in newspaper articles were domestic actors, who limited their critiques and campaigns to the national arena. Where the domestic branch of a European or transnational participant (such as Amnesty International or Anonymous) predominated, we coded as both domestic and EU/or transnational. A participant was coded as European or transnational if its title or aims covered either the geographical scope of Europe or for transnational participants, beyond Europe. Participants were also coded as European if membership clearly extended to groups in other European countries. They were coded as transnational if that membership clearly extended beyond Europe. Mixed categories involved participants from various territorial arenas, for example, a conference on the ESD crisis which included academics, activists, unionists, artists from domestic, European and transnational arenas. ${ }^{5}$

Issues were perhaps the most difficult dimension to code as either domestic, European or transnational in a consistent manner. An 'issue' can be defined as 'the substantive content of the claim, stating what is to be done (aim) and (why?)' (Koopmans and Erbe, 2003: 9). In many cases, the territorial scope of the issue frame was clear from the way in which participants targeted their claims to authorities in particular territorial arenas or from the membership of the organizations set up to campaign on particular issues. Other times, the territorial scope of the issue was extrapolated from the claims made by activists themselves. In some instances issues were articulated in one arena, but had clear relevance beyond it. For example, the actions of the Spanish organization Plataforma Afectados por la Hipoteca (Platform Affected by Mortgage), which campaigned for the rights of Spanish mortgage holders, dealt with an issue that potentially related to policies enacted by local, regional, state, eu and international authorities and the conduct of domestic, European and transnational banking organizations. The

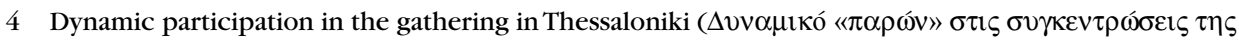

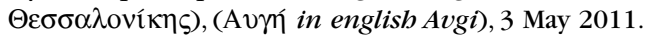

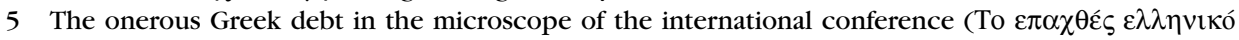

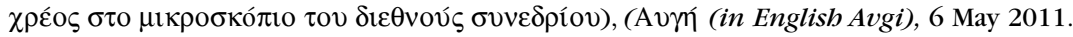


broad scope of the issue at the heart of the organization's objective was particularly apparent in the context of the transnational financial crisis, where $E U$ authorities played a crucial role and in a state (Spain) which was so seriously affected by the ESD crisis. However, protests outside the homes of people facing eviction organized by PAH and (often supported by M-15 activists) were coded as a domestic issue, because the acts themselves primarily targeted Spanish authorities and banks in Spain, and sought to highlight injustices in Spanish banking practices. ${ }^{6}$ In short, we considered an issue as domestic if it was specifically linked to a domestic decision or a domestic political arena even if it could, in general, be related to a broader EU or transnational issue (other examples include rights of children, political violence or xenophobia).

We coded identity statements from reported speeches of activists. Identity statements included references to solidarity, communities of fate and interest and included both territorial identities and social identities formed around cleavages including class, gender, generations, but also movements themselves. Identity statements were categorized as domestic, European and transnational depending on the content of those statements. In some instances, speakers specifically referred to territorially defined identities, such as references to the plight of 'young Spaniards' by the platform Juventud Sin Futuro (Youth Without Future), or reports of placards in the Plaza del Sol occupation in May 2011 referring to 'Peoples of Europe, rise up'. Transnational identities referred more generally, for example, to 'all humanity' or all those who inhabit 'the world'. Other times, the territorial scope of identity statements were less explicit, but could be gleaned from other information provided by the context in which identity statements were made. This was most common for statements categorized as domestic identity statements. For instance, statements by $15 \mathrm{M}$ activists on movement identity - such as claims that the movement was non-violent and non-partisan - were coded as domestic when made in the context of protests targeting domestic institutions or referring to domestic events. Movement identities were also coded as domestic if made by organizations primarily operating in the domestic arena, such as those by activists of the various victims of terrorism associations in Spain.

As mentioned above, we only coded instances of what Koopmans and Statham define as strong horizontal Europeanization (and transnationalization) because this concept focuses on communicative linkages between ac-

6 Riera, J 'Activistas del 15-M vuelven a impedir dos desahucios judiciales', El Mundo, 17 June 2011. 
tors at different territorial levels. As it will be recalled, horizonal referencing of this kind occurs when there is also 'a communicative link in the structure of claim-making between actors in different countries' or 'actors from one country explicitly address or refer to actors or policies in another European country' (Koopmans and Statham, 2010:38). When references were made to groups, policies or events in another European country (or groups of them) we coded these as European. Most horizontal referencing was made by Spanish or Greek activists to activists in other countries. When references were made to groups, policies or events in countries (or groups of them) beyond Europe we coded these as transnational. In some instances, horizontal referencing took the form of direct interpersonal communication, learning and exchange of information between activists from different countries. For example, when a newspaper article reports protestors in Greece making references to the Indignados in Spain, these references were coded as horizontal Europeanization. ${ }^{7}$ However, it was not necessary for activists to be Spanish for horizontal referencing to occur and we coded as such. For example, manifestations in Paris to protest against eviction of protestors occupying the Plaza de Catalunya in Barcelona were coded as horizontal Europeanization. ${ }^{8}$

\section{FINDINGS OF THE PILOT STUDY}

As Figure 1 shows, the largest number of events in both Spain and Greece were characterized as non-Europeanized, which occurs when all dimensions are characterized as domestic. In Spain a total of 144 out of 163 events examined were classed as non-Europeanized. In other words, the pilot study shows that non-Europeanized events were not only the largest category, there were many more events in which there was no Europeanization (88\%) than there were events with at least one dimension of Europeanization (12\%). In Greece, the largest category of events examined were also classified as non-Europeanized, with 55 out of 148 events. However, in contrast to the Spanish case, in Greece many more events exhibited at least one dimension of Europeanization (63\%) than the number of those that exhibited no Europeanization at all (37\%). In other words, Europeanization is significant in Greece, but not in Spain.

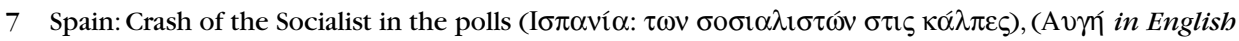
Avgi), 24 May 2011.

8 'Los desalojados del 15-M de Lleida denunciarán a los Mossos', Publico.es, 31 May 2011. 
The results of the pilot study are presented in Figure 1.

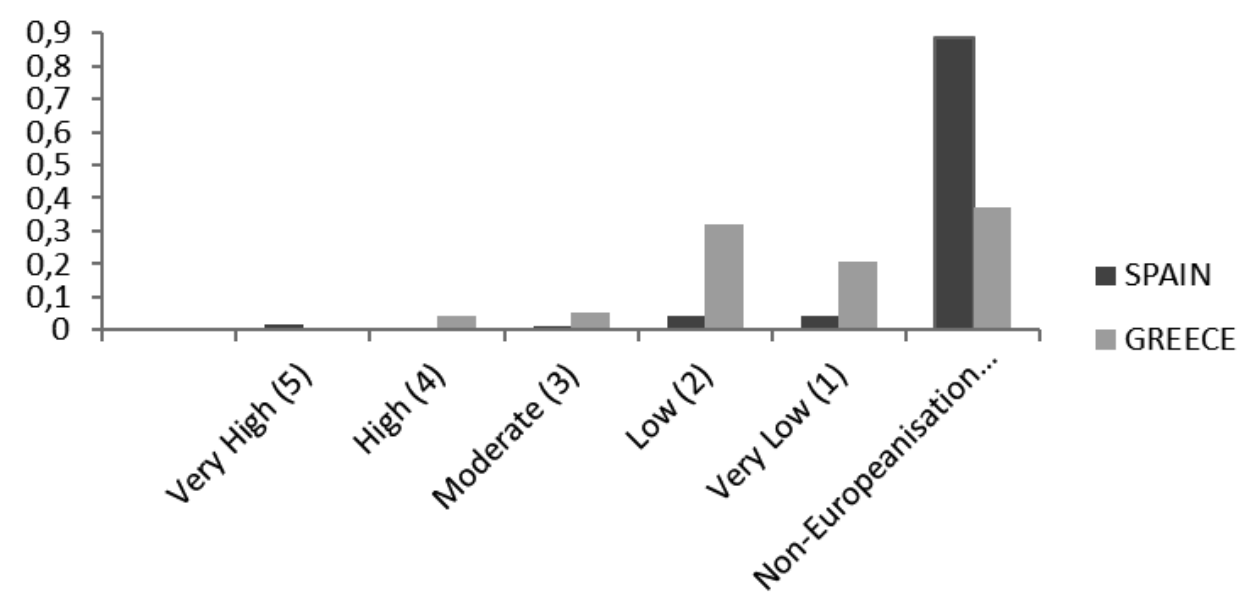

Figure 1

Degrees of Europeanization (in Percentages)

We can begin to account for this finding with reference to disaggregated data presented in Figure 2.

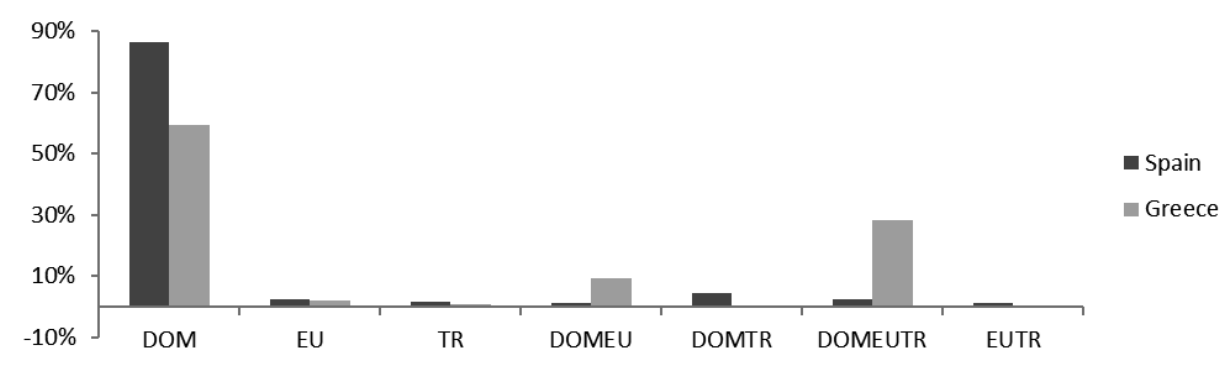

Participants (percentage of events) 


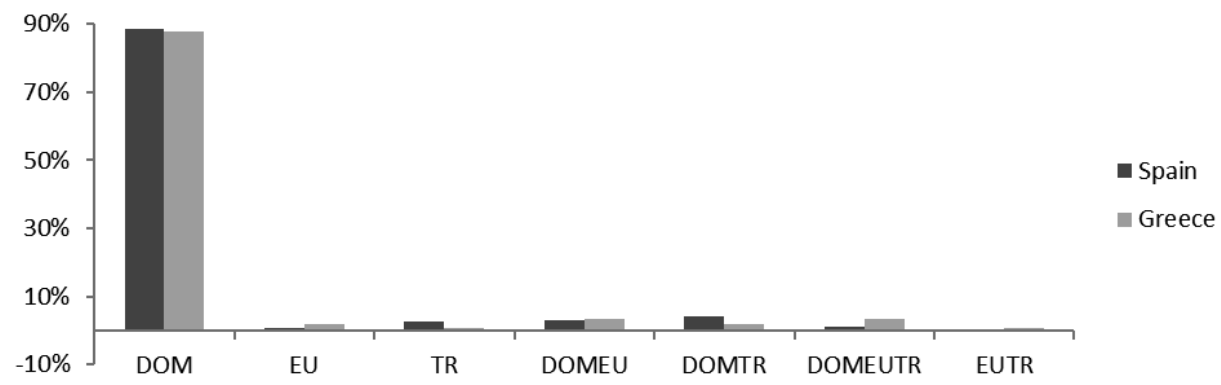

Issues (percentage of events)

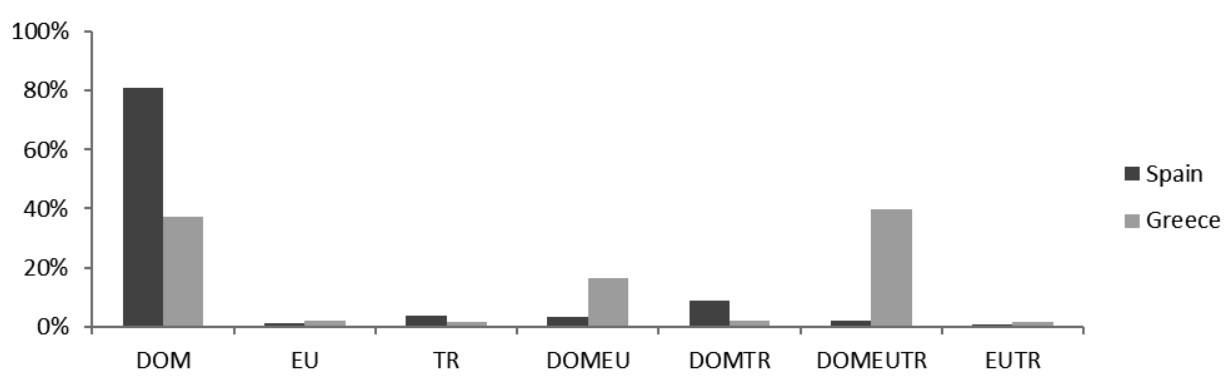

Identification (percentage of events)

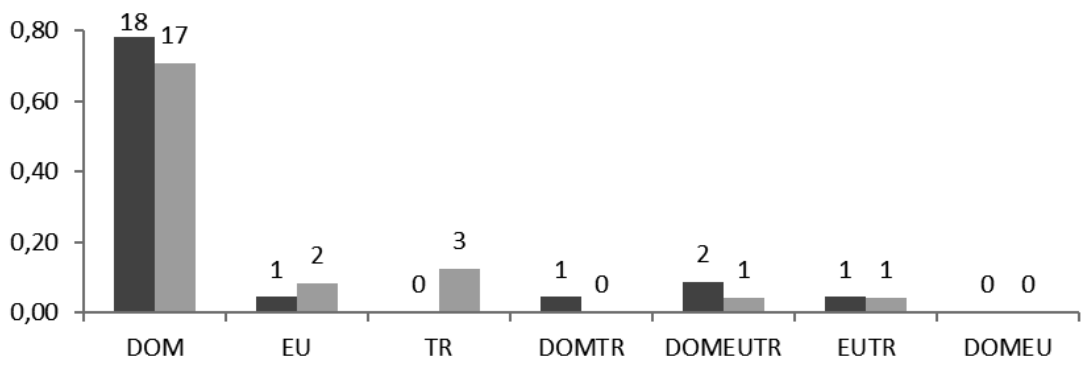

- Spain

Greece

DOM=Domestic; $\mathrm{EU}=$ European; $\mathrm{TR}=$ Transnational; $\mathrm{DOMEU}=$ Domestic and European; $\mathrm{DOMTR}=$ Domestic and Transnational; DOMEUTR=Domestic, European and Transnational and EUTR=European and Transnational.

Horizontal referencing (number of events) 


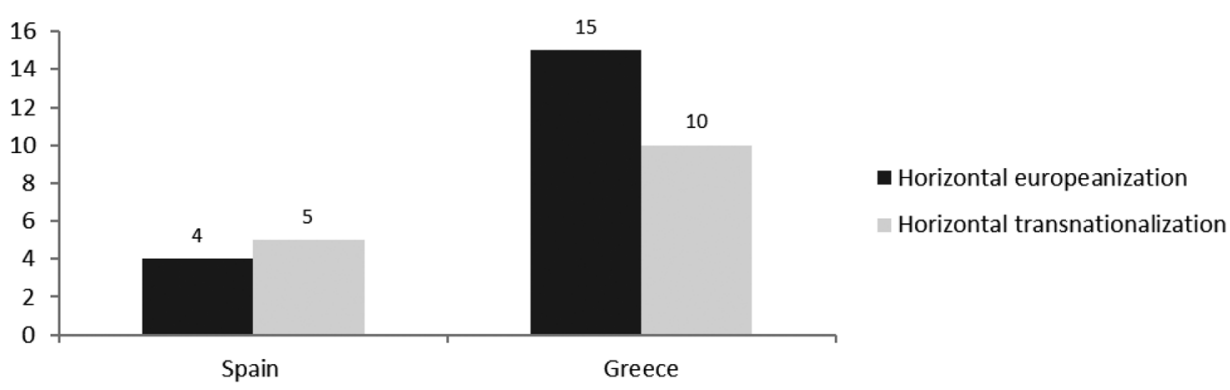

Note:The numbers on top of each column indicate the total number of events with identity statements.

Figure 2

Territorial dimensions of social movement targets, participants, issue frames, identification and horizontal referencing

This data shows that for almost all of the dimensions, social movement activity can be largely characterized as domestic in orientation. In both Spain and Greece social movements targeted domestic actors in their protests more often than other kinds of actors, although it is notable that in Greece, the second highest target type is a composite category, where social movements targeted domestic, eu and transnational actors simultaneously. In both Spain and Greece most participants were characterized as domestic actors while identity statements, when made, mostly referred to identities territorially bound by the state, such as national identities, or movement identities. Regarding issues, it was most common for social movement actors in Spain to frame issues as domestic. However, in an indication of the source of significant differences between the two cases it can be seen that in Greece, the most common kind of issue framing was a composite category, where issues were framed simultaneously as domestic, European and transnational. We found very little evidence of horizontal referencing, perhaps reflecting the observation that newspaper articles are not the discursively most rich source of data (Koopmans and Statham, 1999: 216).

Our last finding picks up on the above-mentioned methodological critique that Europeanization research tends to overestimate the importance of Europe as an explanatory factor for domestic changes. As mentioned previously, and as Figure 2 shows, there is a non-negligible number of events where all three territorial arenas are relevant in a single dimension. This is 
most apparent for the issues dimension, where $40 \%$ of events were categorized as domestic, European and transnational simultaneously in Greece (although only $4 \%$ of events for Spain). It is also relevant in the targets category for Greece, where $28 \%$ of events were categorized as domestic, European and transnational simultaneously, although again at a lower level in Spain with $2 \%$. Figure 3 also shows that Europeanization of social movements has been accompanied by processes of transnationalization.

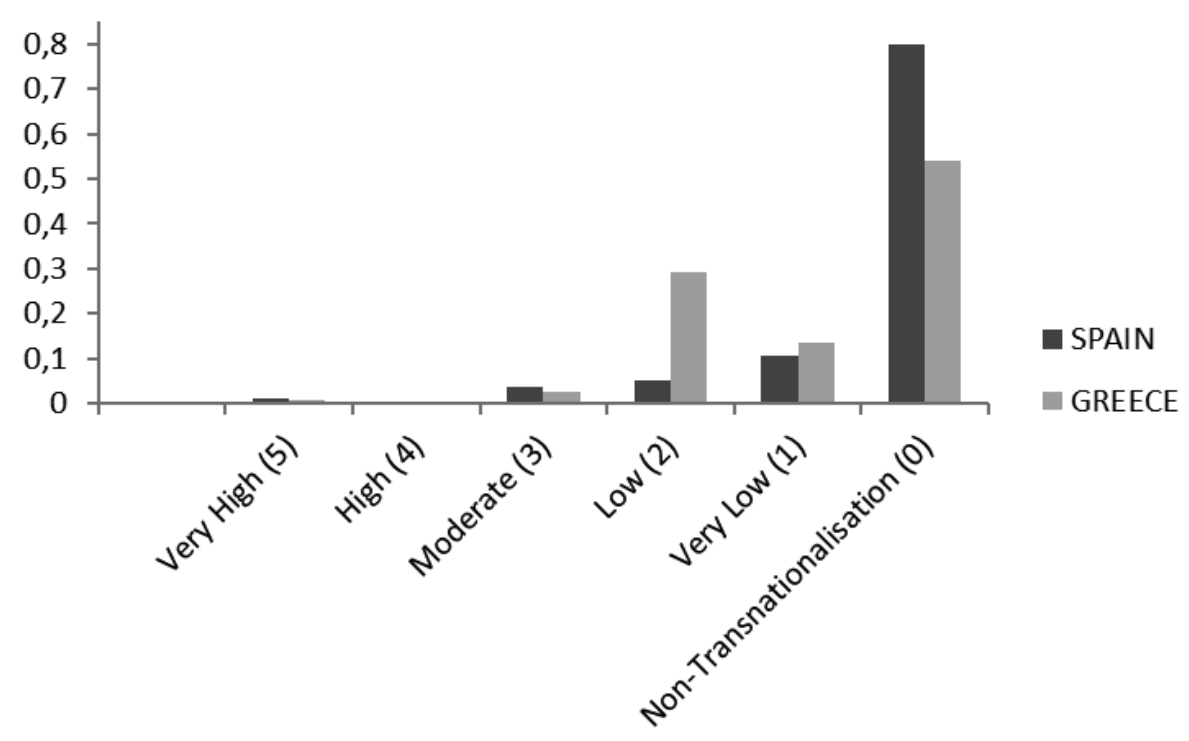

Figure 3

Degrees of Transnationalization (in Percentage)

It also notable that there are some parallels in the frequency with which events are categorized as a different degree of Europeanization and Transnationalization in each of the two countries. Figures are too low to meaningfully compare 'very high', 'high' and 'moderate' categories in each of the two countries. However, Spanish events categorized in the 'very low' category were similar - $4 \%$ of events have a Europeanization dimension and $1 \%$ have a Transnationalization dimension - while in the 'low category' $4 \%$ of events 
were categorized as Europeanization and 5\% as Transnationalization. Similarly, in Greece, $21 \%$ of events correspond to Europeanization in the 'very low' category while there are $14 \%$ for Transnationalization. In the 'low' category the percentages for Greece were 32\% and 29\% respectively. This suggest that separating out Europeanization and Transnationalization processes may be problematic, but that more work is needed to conceptualise how the two processes are interrelated.

\section{DIRECTIONS FOR FUTURE RESEARCH}

In the first place, our research suggests that the Europeanization of social movements in the context of the ESD crisis is worthy of further research.This is because in at least one of the cases - Greece - there were more events with at least one dimensions of social movement Europeanization than those that showed no dimensions of Europeanization. Further research will need to determine whether the periods under examination in both countries represent broader trends. It may be that Europe becomes more or less important at different times. In order to focus on the importance of the ESD crisis in mobilization, it will be necessary that this extended time frame include periods before and after the crisis. It would also be fruitful to examine a broader range of cases, including states that have emerged through the course of the crisis as creditor countries (such as Germany or Denmark) and debtor countries (such as Portugal, Cyprus or Ireland).

The very clear variation between the Spanish and Greek cases - both in the 'eye of the storm' of the ESD crisis, at least during the period studied - suggests particular attention should be paid to accounting for variation among the cases. In our pilot study, for instance, a careful reading of newspaper articles in the sample indicated that differences in the degree of Europeanization might be explained by the different roles played by EU institutions and the IMF in managing the ESD crisis in the two countries. At the time of the sample (May and June 2011), many protests in both countries focused on the economic crisis and its consequences, such as budget cuts, housing evictions, or changes to working conditions. Greece had obtained the first of three bailouts from the EU and the IMF and was negotiating a second, while Spanish banks were only given a bailout, under much softer terms, at a date later than the time of our sample. While social movements in both countries did focus critical attention on the activities of the EU (and transnational) organizations in their protests, it was much more 
common for Greek activists to claim that the domestic, eu and transnational political elites were equally responsible for the crisis and its management. The frequent visits of the Troika to Greece at this time, which coincided with negotiations for a second bailout, were the focus of many protest activities. In contrast, crisis-related activism, particularly mobilization by movements such as $15 \mathrm{M}$, focused much more attention on critiques of the democratic credentials of the political class. Other explanatory hypotheses for variation among the cases that could influence case selection for future studies could reflect the hypothesis that varying degrees of social movement moblizations may reflect varying degrees of Euroscepticism in the member states or that mobilization outside the state may be more common where domestic opportunity structures are more closed to civil society penetration. And finally, analysis of different kinds of data can be employed to supplement that of newspapers, especially from websites of specific organizations and social media postings. This is particularly important for examining the significance of the dimensions of 'horizontal referencing' and 'identification' which newspaper articles did not address in much detail. Analysis of this kind of data may also generate new hypotheses about the relationship between Europeanization and Transnationalisation, which our data suggests are both prevalent to a significant extent in contentious action, at least during the period we examined.

\section{REFERENCES}

Bourne, A. (2014): «European identities: Conflict and Cooperation», in LyNgaARD, K., I. Manners, and K. Löfgren, Research Methods in European Union Studies, Houndsmills, Palgrave MacMillan, pp. 5571.

Castels, M. (2012): Networks of Outrage and Hope, Cambridge, Polity Press. CASTAÑEDA, E. (2013): «The Indignados of Spain: A Precedent to Occupy Wall Street», Social Movement Studies, 11(3-4), pp. 309-319.

Della Porta, D. and M. Caiani (2009): Social Movements and Europeanization, Oxford, Oxford University Press.

Della Porta, D. and S. Tarrow (2005): Transnational Protest and Global Activism, Rowman and Littlefield Publishers.

Della Porta, D., M. Caiani and C.Wagemann (2012): Mobilizing on the extreme right: Germany, Italy, and the United States, Oxford, Oxford University Press. 
Della Porta, D and A. Mattoni, A (eds.) (2014): Spreading Protest, Essex, ECPR Press.

Flesher Forminaya, C. and L. Cox (2013): Understanding European Movements, London, Routledge.

Flesher Forminaya, C. (2014): Social Movements and Globalisation, Houndsmills, Palgrave Macmillen.

Hughes, N. (2011): "Young people took to the Streets and all of a Sudden all of the Political parties got old: The 15M Movement in Spain», Social Movement Studies, 10(4), pp. 407-13.

IMIG, D. and S. TARrow (2000): «Political contention in a Europeanising polity», West European Politics, 23(4), pp. 73-93.

Kaldor M., S. Selchow, S. Deel, T. and Murray-Leach (2013): «The 'Bubbling Up' of Subterranean Politics in Europe», Project Report Civil Society and Human Security Research Unit, London School of Economics and Political Science. Available at: http://eprints.lse.ac.uk/44873/1/The\%20 \%E2\%80\%98bubbling\%20up\%E2\%80\%99\%20of\%20subterranean $\% 20$ politics\%20in\%20Europe(lsero).pdf.

Koopmans, R. and D. Rucht (2002): «Protest Event Analysis» in KLAndermans B., and S. STAggenborg (eds): Methods of Social Movement Research, Minneapolis, University of Minnesota Press, pp. 231-259.

KoOpmans, R. and P. STATHAM (1999): «Political Claims Analysis: Integrating Protest Event and Political Discourse Analysis», Mobilisation, 4(1), pp. 203221.

Koopmans R. and J. Erbe (2003): «Towards a European Public Sphere? Vertical and Horizontal Dimensions of Europeanised Political Communication», Best.-Nr. SP IV 2003-403 Wissenschaftszentrum Berlin für Sozialforschung (WZB).

KoOpmans, R. and P. STAтHAм (eds) (2010): The Making of a European Public Spbere: Media Discourse and Political Contention, Cambridge, Cambridge University Press.

KoOpmans, R., J. ERBe and M. F. MeYer (2010): The Europeanization of Public Spheres: Comparisons across Issues, Time and Countries, Cambridge, Cambridge University Press.

Kousis, M. (2014): «The Transnational Dimension of the Greek Protest Campaign against Troika Memoranda and Austerity Policies, 2010-12», in Della Porta, D and A. MatToni (eds): Spreading Protest, Essex, ECPR press, pp. 137-170. 
LYNGGAARD, K. (2011): «Domestic change in the face of European integration and globalization: Methodological pitfalls and pathways», Comparative European Politics, .9(1), pp. 18-37.

Marks G. and Mcadam (1996): «Social Movements and the Changing Structure of Political Opportunity in the European Union», West European Politics, 19(2), pp. 249-278.

MCCARTHY. J., C. MCPHAIL and J. SMITH (1996): «Images of Protest: Dimensions of Selection Bias in Media Coverage of Washington Denmonstrations, 1982 and 1991», American Sociological Review, 16(3), pp. 478-499.

Psimitis, M. (2011): «The protest Cycle of Spring 2010 in Greece, Social Movement Studies: Journal of Social Protest», Cultural and Political Protest, 10(2), pp. 191-197.

RADAELLI, C. (2004): «Europeanization: Solution or problem?», European Integration online Papers, 8(16), pp. 1-26.

ReIsING, K. (1999): «United in Opposition? A Cross-National Time-Series Analysis of European Protest in Three Selected Countries, 1980-1995», The Journal of Conflict Resolution, 43(3), pp. 317-342.

Rucht, D. (2002): «The Eu as a Target of Political Mobilisation: Is there a Europeanization of Conflict?» In Balme, R., D. Chabanet, and V. Wright (eds.): L'action Collective en Europe, Paris, Presses de Sciences Po., pp. 110-137.

Sмiтh, J. (2007): «Transnational Processes and Movements in Snow», in Soule D,m and H-P. KrIESI, (eds): The Blackwell Companion to Social Movements, Oxford, Blackwell, pp. 311-335.

Sмітн J. (2002): «Organizing for Global Change: Organizational Strength and Strategic Framing» in Transnational Social Movement Organizations. Unpublished Paper, Stony Brook, NY.

TARrow, S. (1995): «The Europeanization of Conflict. Reflections from a Social Movement Perspective», West European Politics, 18, pp. 223-251

Tejerina, B. Perugorria, I. Benski, T and Langman, L (2013): «From indignation to occupation:A new wave of global mobilization», Current Sociology, 61(4), pp. 377-392.

Worth, O. (2013): Resistance in the Age of Austerity, London, Zed Books. 


\section{APPENDIX 1}

Number of events for each 'degree' of Europeanization and Transnationalization

\begin{tabular}{|c|c|c|c|c|}
\hline \multirow{2}{*}{$\begin{array}{l}\text { Degree of Euro- } \\
\text { peanization/ } \\
\text { Transnationali- } \\
\text { zation }\end{array}$} & \multicolumn{2}{|l|}{$\begin{array}{l}\text { SPAIN } \\
(163)\end{array}$} & \multicolumn{2}{|c|}{ GREECE (148) } \\
\hline & $\begin{array}{l}\text { Europeani- } \\
\text { zation }\end{array}$ & $\begin{array}{c}\text { Transnationali- } \\
\text { zation }\end{array}$ & $\begin{array}{l}\text { Europeani- } \\
\text { zation }\end{array}$ & $\begin{array}{l}\text { Transnationali- } \\
\text { zation }\end{array}$ \\
\hline Very High (5) & 3 & 2 & 1 & 1 \\
\hline High (4) & 0 & 0 & 6 & 0 \\
\hline Moderate (3) & 2 & 6 & 8 & 4 \\
\hline Low (2) & 7 & 8 & 47 & 43 \\
\hline Very Low (1) & 7 & 17 & 31 & 20 \\
\hline $\begin{array}{l}\text { Non-Europeani- } \\
\text { zation/ Non } \\
\text { Transnationalisa- } \\
\text { tion (0) }\end{array}$ & 144 & 130 & 55 & 80 \\
\hline
\end{tabular}

Source: compiled by authors 